\title{
Redescription of Anopheles (Nyssorhynchus) antunesi Galvão \& Amaral and description of a new species of the Myzorhynchella Section (Diptera: Culicidae) from Serra da Mantiqueira, Brazil
}

\author{
Sandra Sayuri Nagaki', Monique de Albuquerque Motta ${ }^{2}$, Maria Anice Mureb Sallum¹/+ \\ 12Departamento de Epidemiologia, Faculdade de Saúde Pública, Universidade de São Paulo, Av. Dr. Arnaldo 715, 01246-904, São Paulo, \\ SP, Brasil '2Laboratório de Transmissores de Hematozoários, Instituto Oswaldo Cruz-Fiocruz, Rio de Janeiro, RJ, Brasil
}

Anopheles (Nyssorhynchus) pristinus Nagaki \& Sallum, n. sp. of the Myzorhynchella Section is described based on morphological characters of adult females, males, fourth-instar larvae, pupae and male genitalia. Anopheles (Nyssorhynchus) antunesi Galvão \& Amaral is characterized to fix its identity and distinguish it from An. pristinus. The eggs of An. antunesi are described for the first time. Molecular characterization employing sequences of the COI mitochondrial gene and the ITS2 region of ribosomal DNA are provided for each species. An. antunesi and An. pristinus are compared with morphologically similar species of the Myzorhynchella Section. The results of the present study suggest that the new species has been misidentified as both An. antunesi and Anopheles lutzii Cruz. An. antunesi and An. pristinus are sympatric, occurring at high altitudes in Serra da Mantiqueira, Southeastern Brazil.

Key words: COI - ITS2 - morphology - Serra da Mantiqueira - new species

The genus Anopheles Meigen includes 458 species, which are subdivided into seven subgenera (Harbach 2008). The subgenus Nyssorhynchus Blanchard includes some of the most important vector species of human malaria parasites in Central and South America (Sallum \& Wilkerson 1997) and is divided into three sections, the Albimanus, Argyritarsis and Myzorhynchella Sections (Harbach 2008). The Albimanus Section includes 19 formally recognized species (Faran 1980), the Argyritarsis 11 species (Linthicum 1988, Rosa-Freitas 1989, Motoki et al. 2009) and the Myzorhynchella four species, i.e., Anopheles lutzii Cruz, Anopheles parvus (Chagas), Anopheles nigritarsis (Chagas) and Anopheles antunesi Galvão \& Amaral (Galvão 1941). These four taxa were described from specimens collected in Brazil (Belkin et al. 1971) and there is no epidemiological evidence supporting the involvement of any Myzorhynchella species as vectors of pathogens.

Galvão \& Amaral (1940) described An. antunesi based on morphological characters of all life stages, including eggs. Specimens were from Vila Emilio Ribas, municipality of Campos do Jordão, Serra da Mantiqueira, Southeastern Brazil. Since the description of An. antunesi, few studies have been conducted for species of the Myzorhynchella Section. Galvão (1941) described and illustrated the eggs and the male genitalia of specimens of An. antunesi collected in Casa Grande, a forest

Financial support: FAPESP (2005/53973-0 to MAMS, Master fellowship 07/01870-8 to SSN), CNPq (BPP 300351/2008-9 to MAMS)

+Corresponding author: masallum@usp.br

Received 17 December 2009

Accepted 1 April 2010 reserve in the Serra do Mar within the Mata Atlântica, in municipality of Salesópolis, state of São Paulo (SP). More recently, Forattini et al. (1997) described the eggs of An. antunesi from specimens collected in Campos do Jordão, Serra da Mantiqueira.

The type specimen of An. antunesi was deposited in the Faculdade de Medicina, Universidade de São Paulo (FMUSP) (Galvão \& Amaral 1940). The FMUSP collection was transferred to the Faculdade de Saúde Pública (FSP) of USP in the late 1960s; however, except for one adult female paratype (E-2034) (Forattini et al. 1970), no other type specimen of An. antunesi was found among the individuals in the FMUSP collection. It is likely that the holotype of An. antunesi is either lost or deposited in an unknown collection.

While examining specimens of An. antunesi from Serra da Mantiqueira, we observed that they could be separated into two morphological forms based on the pattern of pale and dark wing spots and characters of the larvae and male genitalia. One morphological form corresponds to An. antunesi, whereas the second form belongs to an undescribed species. The objective of this paper is to describe the new species of the Myzorhynchella Section and to characterize An. antunesi employing both morphological characters and DNA sequence for the ITS2 region of ribosomal DNA and the COI mitochondrial gene.

\section{MATERIALS AND METHODS}

Females were collected in a Shannon trap in the vicinities of the Parque Nacional do Itatiaia, municipality of Itatiaia, state of Rio de Janeiro (RJ), Brazil (-22.41630556S 44.62213889W, Datum SAD69) and in Pico do Itapeva, municipality of Pindamonhangaba, SP, Brazil (-22.75847222S -45.51527778W, Datum SAD69). Eggs were collected from two females of each locality. Females were blood-fed and one wing was removed 
$48 \mathrm{~h}$ later to induce oviposition. Eggs were fixed in Bouin's solution $36 \mathrm{~h}$ after oviposition and prepared for scanning electron microscopy (SEM) following the protocol described by Forattini \& Marucci (1993). External morphology of the eggs was examined in a JEOL-P15 scanning electron microscope (JEOL, Japan).

Morphological characters of the adult females, males, fourth-instar larvae, pupae and male genitalia were examined. Abbreviations for the life stages are: F: adult female; M: adult male; G: male genitalia; L: larva; P: pupa; Le: larval exuviae; Pe: pupal exuviae; E: eggs. Terminology for morphological characters follows Harbach \& Knight (1980). The nomenclature of the wing veins follows Belkin (1962), and the terminology for wing spots follows Wilkerson \& Peyton (1990). Specimens used in this study are deposited in the Entomological Collection of the FSP-USP.

Sequences of the ITS2 of ribosomal DNA and COI barcode subunit of the mitochondrial genome were generated for six specimens of An. antunesi and 12 specimens of Anopheles pristinus. Genomic DNA was extracted from individual mosquitoes following the insect DNA extraction protocol provided by the QIAgen DNeasy ${ }^{\circledR}$ Blood and Tissue Kit (QIAgen Ltd, Crawley, UK). For one specimen of An. antunesi, only the abdomen was used to obtain sequences. The extraction protocol for this specimen was the same used for whole specimens except that the DNA was eluted in $50 \mu \mathrm{l}$ of buffer AE. Considering that the chance of cross contamination was high, DNA was extracted in a flow microbiological safety cabinet.

The ITS2 was amplified using the 5.8SF (5'-ATC ACT CGG CTC GTG GAT CG - 3') and 28SR (5'-ATG CTT AAA TTT AGG GGG TAG TC - 3') primers (Djadid et al. 2007). Polymerase chain reactions (PCR) were carried out in a $25 \mu \mathrm{L}$ reaction mix containing $1 \mu \mathrm{L}$ of DNA of the first elution; $10 \mathrm{mM}$ Tris- $\mathrm{HCl}, \mathrm{pH} 8.3 ; 50 \mathrm{mM} \mathrm{KCl}$; $1.5 \mathrm{mM} \mathrm{MgCl}_{2} ; 2.5 \mu \mathrm{L}$ DMSO; $5 \mathrm{pM}$ of each primer; $200 \mu \mathrm{M}$ each dNTPs; 2.5 U New England Biolabs ${ }^{\circledR}$ Taq polymerase (New England Biolabs, Ispwich, MA); the remaining volume of ultrapure $\mathrm{H}_{2} \mathrm{O}$ up to $25 \mu \mathrm{L}$. Amplification consisted of a 3 min denaturation at $94^{\circ} \mathrm{C}, 34$ cycles at $94^{\circ} \mathrm{C}, 60^{\circ} \mathrm{C}$ and $72^{\circ} \mathrm{C}$ for $30 \mathrm{~s}$ each, followed by a 10 -min extension at $72^{\circ} \mathrm{C}$.

The primers LCO1490 (5'GGT CAA CAA ATC ATA AAG ATA TTG G 3') and HCO2198 (5'TAA ACT TCA GGG TGA CCA AAA AAT CA 3') (Folmer et al. 1994) were used to amplify $658 \mathrm{bp}$ of the COI gene. PCR reactions $(25 \mu \mathrm{L})$ contained $1 \mu \mathrm{L}$ DNA; $10 \mathrm{mM}$ Tris-HCl, $\mathrm{pH}$ $8.3 ; 50 \mathrm{mM} \mathrm{KCl} ; 1.5 \mathrm{mM} \mathrm{MgCl} 2.2 .5 \mu \mathrm{L}$ DMSO; $5 \mathrm{pM}$ of each primer; $200 \mu \mathrm{M}$ each dNTTPs; $2.5 \mathrm{U}$ New England Biolabs ${ }^{\circledR}$ Taq polymerase (New England Biolabs, Ispwich, MA); the remaining volume of ultrapure $\mathrm{H}_{2} \mathrm{O}$ up to $25 \mu \mathrm{L}$. Amplification consisted of a 3-min denaturation at $94^{\circ} \mathrm{C}$ and 35 cycles at $94^{\circ} \mathrm{C}, 55^{\circ} \mathrm{C}$ and $72^{\circ} \mathrm{C}$ for 1 min each, followed by a 7-min extension at $72^{\circ} \mathrm{C}$. COI and ITS2 PCR products were purified using PEG precipitation $(20 \%$ polyethylene glycol 8000/2.5 M NaCl). Sequencing reactions were carried out in both directions using the ABI Big Dye Terminator Kit version 3.1 (PE Applied Biosystems, Warrington, England) with the same primers used for PCR. Sequencing reactions were purified in Sephadex G50 ${ }^{\circledR}$ columns (GE Healthcare). Sequences were analyzed on an ABI Prism 3100 - Avant Genetic Analyzer (Applied Biosystems, Foster City, CA, USA).

Sequences were edited using Sequencher ${ }^{\circledR}$ for Windows version 4.9 (Gene Codes Corporation, Ann Arbor, USA), aligned in CLUSTAL X 1.8 (Thompson et al. 1997) and optimized manually in MacClade version 4.08 (Maddison \& Maddison 2000). Similarity of the ITS2 sequences generated in this study with those previously available in GenBank was assessed using FASTA search (http://www.ncbi.nlm.nih.gov/BLAST/) and documented using PAUP* 4.0 software (Swofford 2003).

Larval and pupal exuviae, male genitalia, wings and legs of the specimens used for DNA extraction are deposited in the FSP-USP as vouchers. Template DNA from this study is retained at $-70^{\circ} \mathrm{C}$ in the FSP-USP for future reference.

\section{An. (Nyssorhynchus) antunesi Galvão \& Amaral}

(Figs 1-4)

An. (Nyssorhynchus) antunesi of Galvão \& Amaral, 1940: 150. Galvão 1941: 552 (taxonomy, bionomics); Rodriguez \& Varela 1962: 246 (first record in Uruguay); Gorham et al. 1967: 42 (distribution, illustrated key); Forattini 1962: 432 (distribution, taxonomy, identification key); Belkin et al. 1971: four (type information, bionomics); Knight \& Stone 1977: 61 (distribution); Forattini 2002: 213 (identification key).

Morphological characterization - An. antunesi can be recognized by the following characteristics of the male genitalia: ventral claspette without spicules, apex narrow (Fig. 1A), ventral surface with distinctly swollen, striated lobes; dorsal claspette with three long setae, most dorsal seta narrow, arising subapically, two large, contorted, flattened ventral setae arising apically; aedeagus long, slender, strongly sclerotized laterally, with a pair of subapical leaflets, leaflets well developed, straight, parallel to the longitudinal axis, strongly sclerotized, serrated on dorsal and lateral surfaces; apex of aedeagus somewhat rounded (Fig. 1E); proctiger membranous, without spicules (Fig. 1C). The adult female can be recognized by having abdominal terga II-VII without scales; variable pattern of pale and dark scales on vein $\mathrm{R}_{4+5}$, mostly pale-scaled, with pale scales medially, with small dark spots at proximal and distal ends; vein $\mathrm{CuA}_{2}$ pale-scaled on proximal 0.5, dark-scaled distally (Fig. $2 \mathrm{~A}$ ); foretarsomeres 1-3 mostly dark-scaled with narrow apical pale rings, foretarsomeres 4,5 entirely dark-scaled; midtarsomere 1 with few pale scales dorsally at apex, midtarsomeres 2-5 dark-scaled; hindtarsomere 1 mostly dark-scaled, with an apical white ring, hindtarsomere 2 dark-scaled on approximately basal 0.5 , white-scaled on apical 0.5, hindtarsomeres 3-5 entirely white-scaled. Based on fourth-instar larvae, An. antunesi can be recognized by the following combination of characters: seta 2-C weakly aciculate, seta 4-C single, long, aciculate; seta 14-P usually with three long, slender branches (Fig. $3 \mathrm{~A})$; seta 1-II-VII palmate, with short pedicel, leaflets ta- 

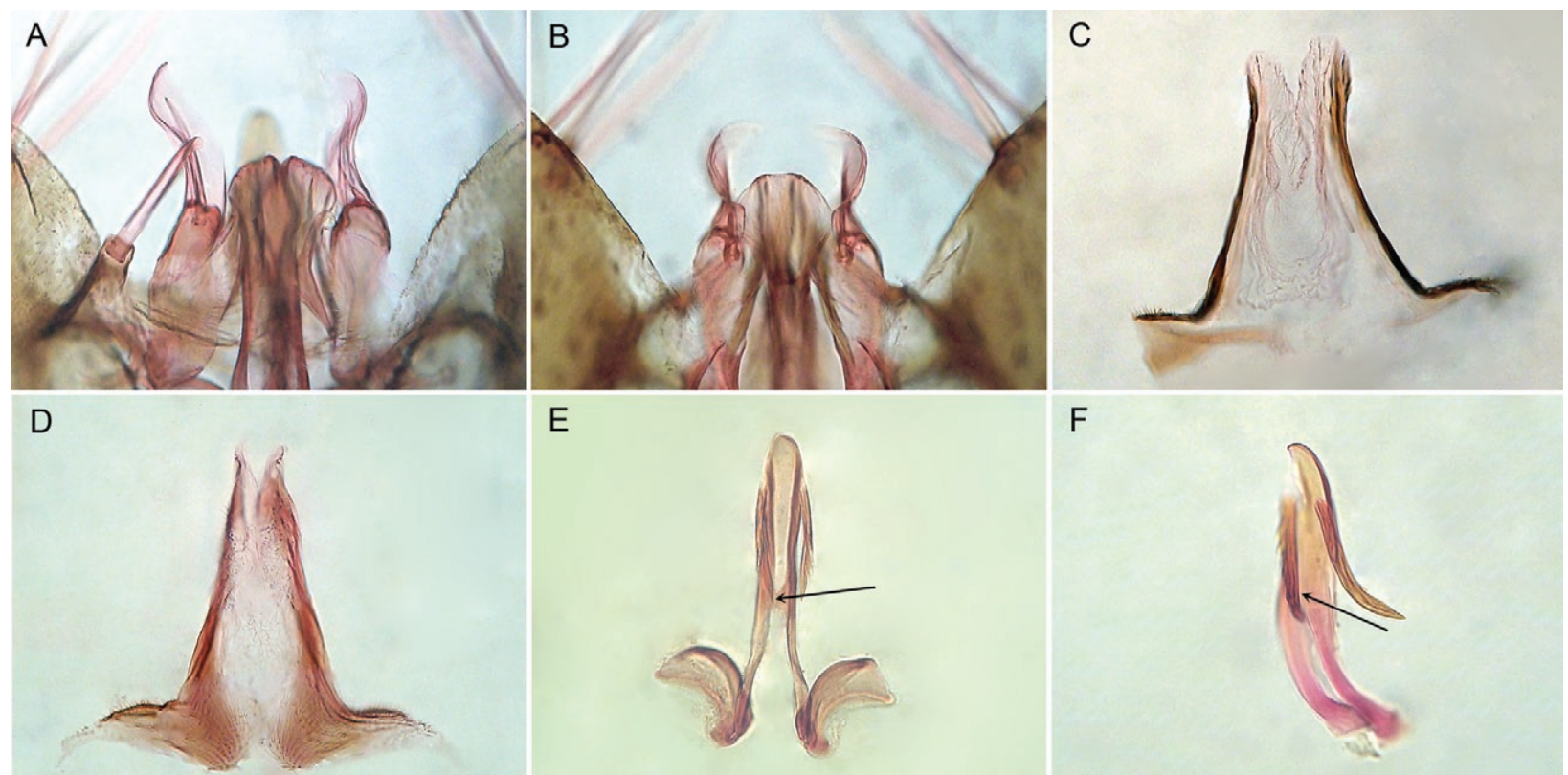

E

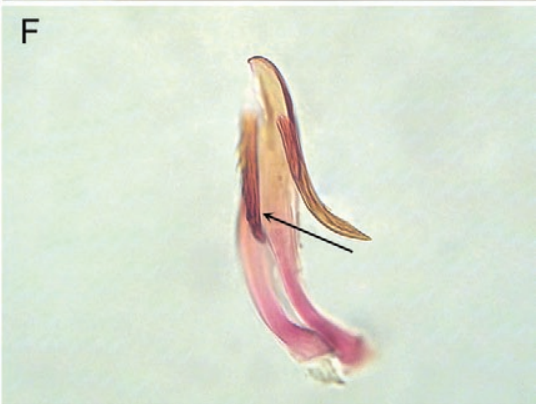

Fig. 1: male genitalia of Anopheles antunesi (A, C, E) and Anopheles pristinus, n. sp. (B, D, F) from Southern Brazil. A, B: ventral claspette (dorsal aspect); C, D: proctiger; E, F: dissected aedeagus showing the position of the ventromesal subtriangular projection.

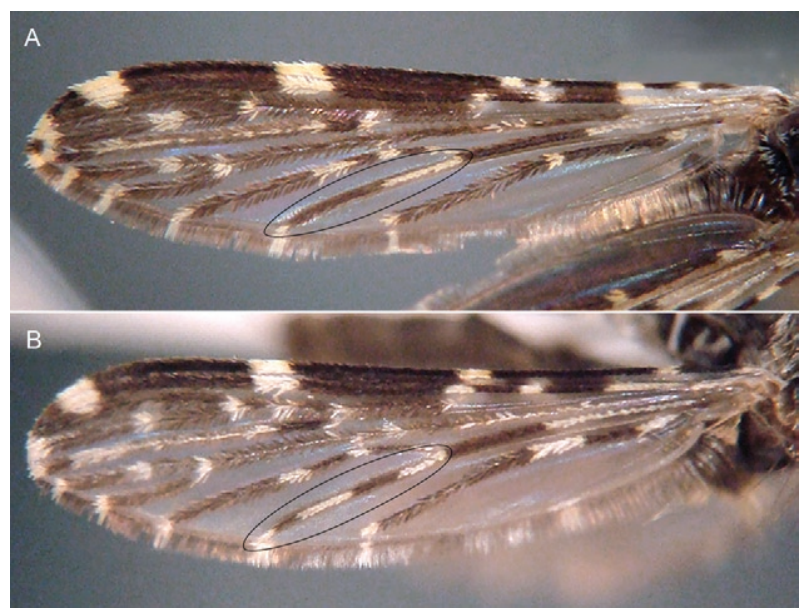

Fig. 2: dorsal surface of the wings of Anopheles antunesi (A) and Anopheles pristinus, n. sp. (B) from Southern Brazil, showing details of the vein $\mathrm{CuA}_{2}$.

pering to apex, ending in a pointed apex (Fig. 3C); 6-IVVI long, bifid (Fig. 3E). Pupae have the trumpet darkly pigmented at midlength, paddle obovate, unpigmented or very weakly pigmented, lighter than posterior abdominal segments, outer edge of paddle distal to external buttress with spicules. Eggs with floats lateral in position, long, covering part of dorsal surface, ribs weakly divided into lobes (Fig. 4A, D); deck narrow, uniformly covered with irregularly shaped tubercles (Fig. 4C); ventral and lateral plastron with somewhat circular pores (Fig. 4B).
Molecular characterization - The amplicon length of the ITS2 sequence was consistent at $472 \mathrm{bp}$ (without the flanking $5.8 \mathrm{~S}$ and $28 \mathrm{~S}$ ). Six sequences revealed a single haplotype comprised of $19.1 \%$ T, $19.3 \%$ A, $28.8 \% \mathrm{C}$ and $32.8 \%$ G. A FASTA search using the Database: nucleotide collection - Optimize for: Somewhat Similar (http:// www.ncbi.nlm.nih.gov/BLAST/) revealed that the ITS2 sequence of An. antunesi shares $77 \%$ similarity with Anopheles pictipennis (Philippi) within a query coverage of $84 \%$. Two unique COI haplotypes were detected in the $658 \mathrm{bp}$ (without the primer regions) fragment. Haplotype 1 is comprised of $39.2 \%$ T, $28.7 \%$ A, $15.8 \%$ $\mathrm{C}$ and $16.3 \% \mathrm{G}$, whereas haplotype 2 is comprised of $39.5 \% \mathrm{~T}, 28.6 \% \mathrm{~A}, 15.5 \% \mathrm{C}$ and $16.4 \% \mathrm{G}$. The ITS2 and COI sequences generated during this study are available in GenBank under the following accessions: ITS2 (GU989324 - GU989329), COI (GU989342 - GU989347, GU989349).

Distribution - An. antunesi was recorded in Brazil (Galvão \& Amaral 1940, Galvão 1940, Forattini 1962, 2002, Gorham et al. 1967), Argentina (Darsie 1985, Gorham et al. 1967) and Uruguay (Rodriguez \& Varela 1962, Gorham et al. 1967). In Brazil, the species was reported in SP, municipality of Campos do Jordão (Galvão \& Amaral 1940, Galvão 1940, Forattini et al. 1997), state of Maranhão (MA), Northeast (Rebêlo et al. 2007), state of Rio Grande do Sul (RS) (Cardoso et al. 2004), municipality of Guaíba (Deane \& Neto 1969) and state of Paraná (PR) (Rachou \& Ricciardi 1951), municipality of Foz do Iguaçu (Consolim et al. 1993). However, in considering the difficulties of identifying species of the 

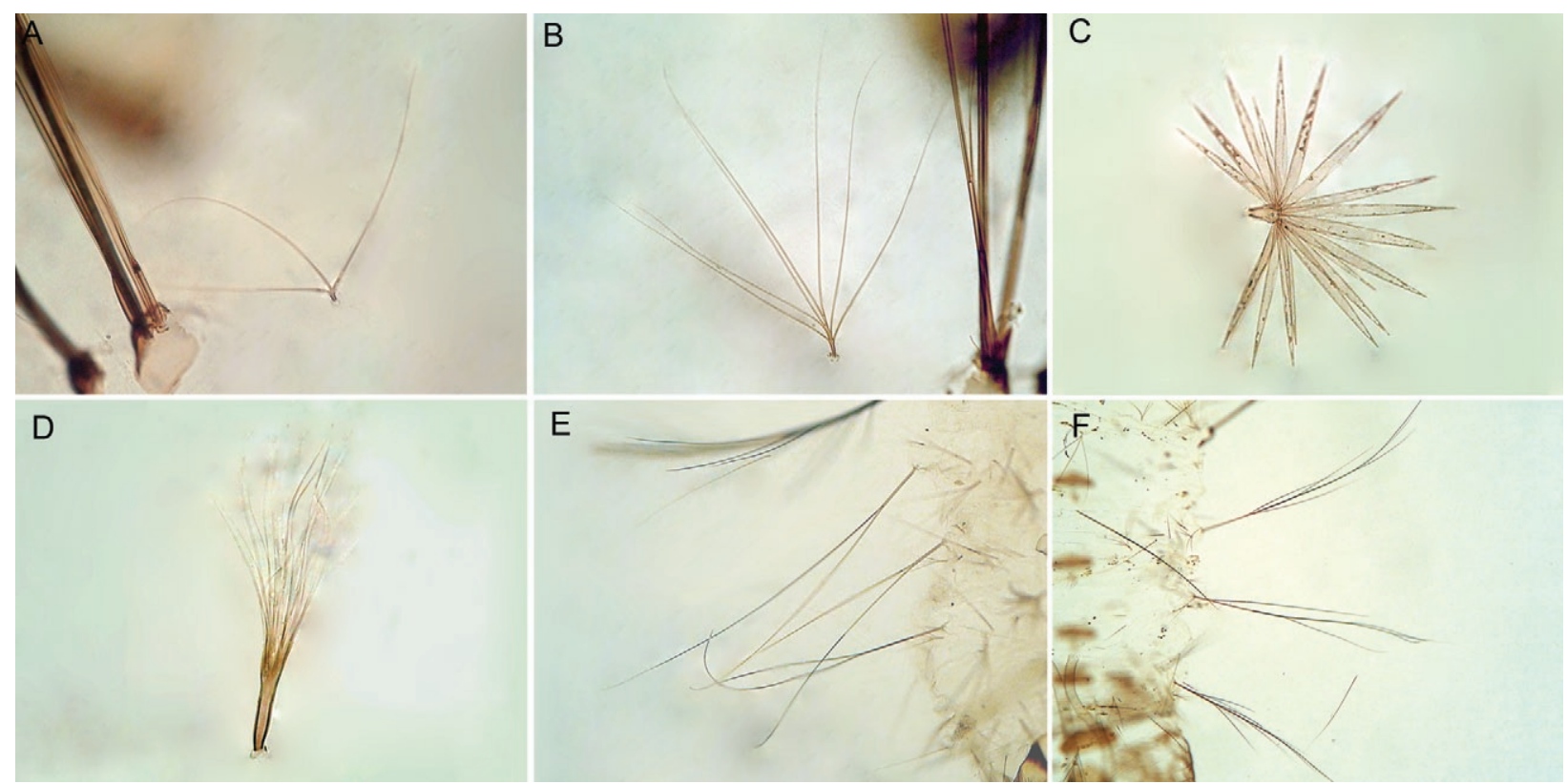

Fig. 3: larval characters of Anopheles antunesi (A, C, E) and Anopheles pristinus, n. sp. (B, D, F) from Southern Brazil. A, B: seta 14-P; C, D: palmate seta 1-II-VII; E, F: seta 6-IV-VI.

Myzorhynchella Section based on morphological characteristics of the adult females, it is likely that the records of An. antunesi in Argentina (Darsie 1985, Gorham et al. 1967), Uruguay (Rodriguez \& Varela 1962, Gorham et al. 1967) and Brazil, in MA (Rebêlo et al. 2007), RS (Cardoso et al. 2004), municipality of Guaíba (Deane \& Neto 1969) and PR (Rachou \& Ricciardi 1951), municipality of Foz do Iguaçu (Consolim et al. 1993) may refer to other species of the Myzorhynchella Section. Consequently, further studies are needed to clarify the distribution of An. antunesi in South America.

Type data - Holotype female (370), allotype male (371), originally deposited in the Collection of the Departamento de Parasitologia da FMUSP, Brazil, both probably lost.

Medical importance - An. antunesi is not known to be of medical importance.

Bionomics - Immature stages of An. antunesi were collected in Vila Emilio Ribas, Campos do Jordão, SP, Serra da Mantiqueira, approximately $1.570 \mathrm{~m}$ above sea level. Larvae were taken from ground pools, small streams and rock holes along the edges of the Capivari River. The habitat was shaded; the water was fresh, clean and cool, with little or no vegetation. No other species of the Anopheles were found associated with An. antunesi (Galvão \& Amaral 1940). In Casa Grande, on the River Claro shores, situated in Serra do Mar, Salesópolis, Galvão (1941) collected immature stages in backwaters of small streams inside forest. Larvae of An. antunesi were also found in a locality in the vicinity of the Parque Nacional do Itatiaia, Serra da Mantiqueira, approximately $1.100 \mathrm{~m}$ above sea level, in backwaters of small streams. The water was fresh, stagnant, cool, well oxygenated, $\mathrm{pH}$ approximately 5 , with decomposing leaves and little vegetation in partial shade. An. antunesi was considered to be zoophilic by Galvão \& Amaral (1940) because during the fieldwork specimens of this species did not bite the collectors. Forattini (1962) made a similar observation about the other Myzorhynchella species. In Casa Grande, Salesópolis, adults were captured at night on horses (Galvão 1941).

Material examined - The specimens of An. antunesi used for morphology were collected in Brazil, SP, municipality of Campos do Jordão, Vila Emilio Ribas, Galvão \& Amaral coll., 1940, Galvão \& Amaral, 1940 det.: E-2034 [Fwing, paratype], E-2038 [MG], E-2042 [FLePe], E-2044 [MLePe], E-2047 [MG], E-2048 [FLe], E-2049 [MG]. SP, municipality of Campos do Jordão, Sallum \& Wilkerson coll., 20-Nov-2001, Sallum, 2001 det.: E-12438 [LePe], E-12449 [LePe], E-12461 [LePe], E-12462 [LePe], E-12463 [LePe], E-12464 [LePe]. SP, municipality of Pindamonhangaba, Pico do Itapeva, Fazenda Saint Claire, Sallum et al. coll., 27-July-2006, Sallum det., 2006: VP09-17 [LePeG]. RJ, municipality of Itatiaia, Parque Nacional do Itatiaia $\left(22^{\circ} 24^{\prime} 58.7^{\prime \prime} \mathrm{S}\right.$ 44'37'19.7'W), Motta coll., July-2007: RJ-0 [FPe]. Motta \& Nagaki coll., 25-March-2008, Sallum \& Nagaki det., 2008, adults were collected in a Shannon trap: RJ03(11) [E], RJ03(12) [E], RJ03(13) [E]. SP, municipality of Salesópolis, Casa Grande, Galvão coll., 1940, det. Galvão, 1940: E-2037 [MG], E-2039 [MLe], E-2041 [MG], E-2050 [MG].

The specimens of An. antunesi used for molecular analysis were collected in Brazil, SP, municipality of Pindamonhangaba, Pico do Itapeva, Fazenda Saint Claire, 

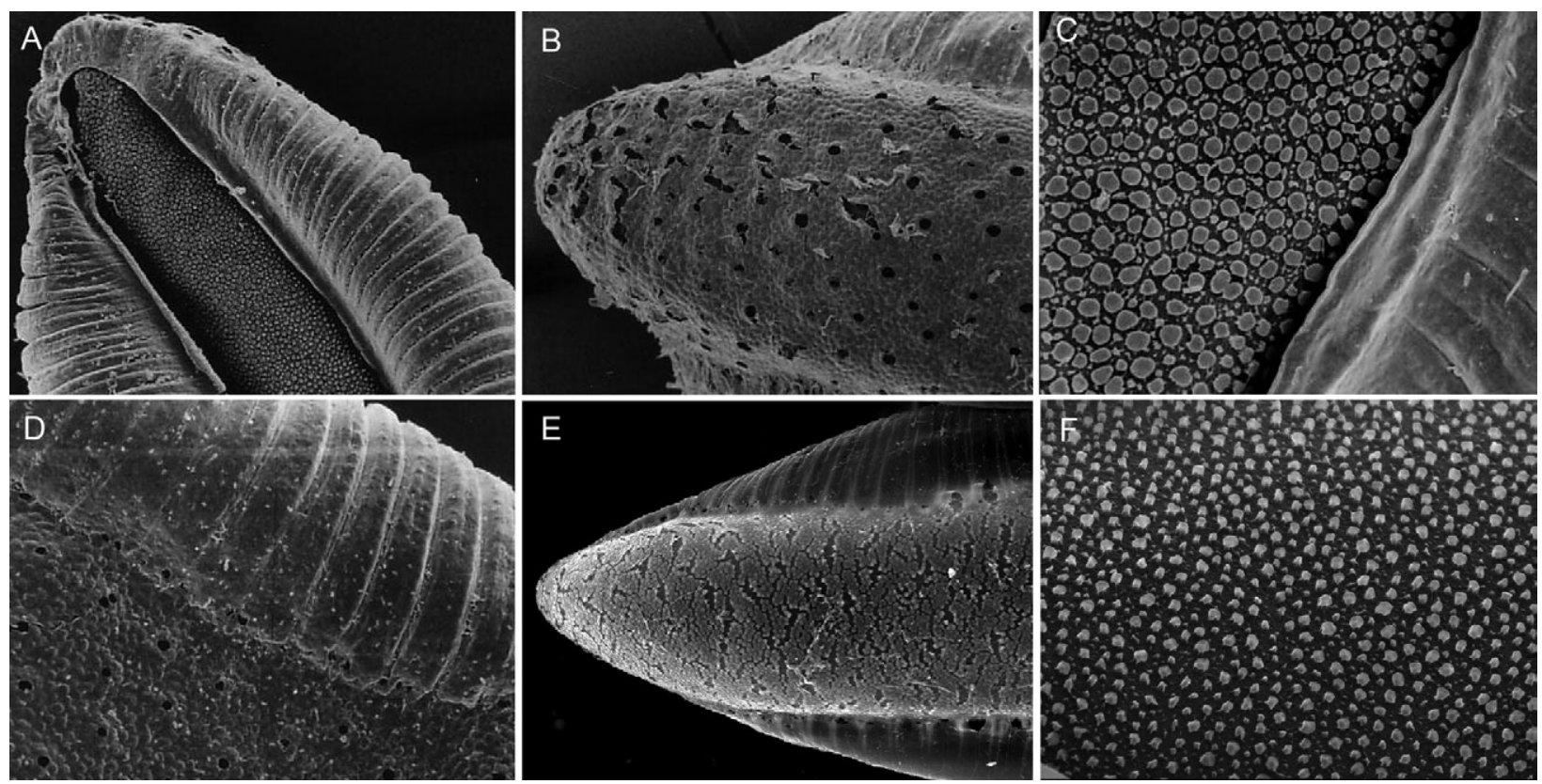

Fig. 4: eggs of Anopheles antunesi (A-D) and Anopheles pristinus, n. sp. (E, F) from Southern Brazil. A: posterior end (ventral view); B, E: posterior end (dorsal view); C, F: deck tubercles and float; D: lateral view of float.

Sallum et al., coll., 27-July-2006, Sallum det., 2006: VP09-17 [M]; adult collected in Shannon trap: VP11b [F], VP11c [F]. RJ, municipality of Itatiaia, Parque Na-

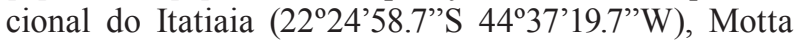
\& Nagaki coll., 25-March-2008, Sallum \& Nagaki det., 2008, adults collected in Shannon trap: RJ03(6) [F], RJ03(11) [F], RJ03(12) [F], RJ03(13) [F].

\section{An. (Nyssorhynchus) pristinus Nagaki \& Sallum, new species}

(Figs 1-4)

An. (Nyssorhynchus) antunesi of Forattini et al. 1998: 120 (SEM eggs).

Morphological characterization - An. pristinus can be recognized by the following characteristics of the male genitalia: ventral claspette without spicules, apex somewhat rounded in shape (Fig. 1B), ventral surface with distinct lobes, median sulcus somewhat V-shaped; dorsal claspette with a narrow dorsal seta arising subapically, two large, contorted, flattened ventral setae arising from apex; aedeagus long, slender, strongly sclerotized laterally, a pair of subapical leaflets, leaflets well developed, strongly sclerotized, serrated, forming an angle of $25^{\circ}$ with aedeagus (Fig. 1F); proctiger membranous mesally, with minute spicules laterally (Fig. 1D), strongly sclerotized at base. The adult female can be recognized by the absence of scales on abdominal terga IIVII; vein $\mathrm{R}_{4+5}$ mostly pale-scaled, with small dark spots at proximal and distal ends; vein $\mathrm{CuA}_{2}$ with two dark spots (Fig. 2B); foretarsomeres 1-3 with narrow, pale apical rings, foretarsomeres 4 and 5 dark-scaled; midtarsomeres 1 and 2 mostly dark-scaled, with few apical pale scales, midtarsomeres 3-5 dark-scaled; hindtarsomere 1 with apical white ring, hindtarsomere 2 dark-scaled at approximately basal 0.5 , white-scaled apically, hindtarsomeres 3-5 white-scaled. Based on characters of the fourth-instar larvae, An. pristinus can be recognized by the following combination of characters: seta 2-C single, seta 4-C single, aciculate; seta 14-P multibranched, with thin branches (Fig. 3B); abdominal seta 0-II-VII min, seta 1-III-VII palmate, with long, narrow pedicel supporting thin, hyaline leaflets (Fig. 3D), seta 6-IV-VI long, with few long branches (Fig. 3F). The pupae can be distinguished by having the trumpet darkly pigmented at midlength, paddle obovate, lightly pigmented, lighter than posterior abdominal segments, outer edge distal to external buttress with spicules. Eggs with floats lateral in position, long, covering part of dorsal surface, ribs weakly divided into lobes; deck narrow, uniformly covered with fine tubercles (Fig. 4F); ventral and lateral plastron with irregular cracked areas (Fig. 4E).

Molecular characterization - The ITS2 region was sequenced for 12 individuals from Campos do Jordão and Pindamonhangaba. The amplicon length was consistent at $470 \mathrm{bp}$ (without the flanking $5.8 \mathrm{~S}$ and $28 \mathrm{~S}$ genes) and the 12 sequences revealed a single haplotype. The ITS2 haplotype comprised 20\% T, 19.6\% A, $27.4 \% \mathrm{C}$ and $33.0 \%$ G. A FASTA search using the Database: nucleotide collection - Optimize for: Somewhat Similar revealed that the ITS2 sequences of An. pristinus share $81 \%$ similarity with An. pictipennis. The fragment of COI was sequenced for 11 individuals, all were same specimens used to obtain ITS2 sequences. Six mtDNA haplotypes were detected in approximately $658 \mathrm{bp}$ (excluding the primer regions). The base compositions were similar for all haplotypes, comprising 
$38 \%$ T, 29\% A, 16\% C and 17\% G. The ITS2 and COI sequences are available in GenBank under the following accessions: ITS2 (GU989330 - GU989341), COI (GU989348, and GU989350 - GU989359).

Distribution - An. pristinus is known only from Serra da Mantiqueira, Southern Brazil. Further studies will be necessary to establish the geographical distribution of $A n$. pristinus and the range of sympatry with An. antunesi.

Medical importance - An. pristinus is not known to be of medical importance.

Bionomics - An. pristinus is a sylvatic species that occurs at high altitudes in cloud forests in Serra da Mantiqueira, Southern Brazil. Field collections were made at Fazenda Saint Claire, Pico do Itapeva, in the border area of municipalities of Pindamonhangaba and Campos do Jordão, at approximately $1.781 \mathrm{~m}$ above sea level. Larvae and pupae were taken from small, deeply shaded ground pools covered with grass. The larval habitat was in an open area outside the forest. The water from a small, slow running stream was fresh, well oxygenated and cool.

Etymology - The name pristinus is Latin for pristine, meaning pure, undamaged, fresh and clean and refers to the habitat were the immature stages were found.

Material examined - Holotype - Pinned adult male with associated larval and pupal exuviae and dissected male genitalia mounted on microscope slides. Brazil, SP, border of municipalities of Pindamonhangaba/ Campos do Jordão, Pico do Itapeva, Fazenda Saint Claire, -22,75847222S, -45,51527778W, Datum SAD69, 27-January-2009, Nagaki et al. coll., specimen SP532, FSP-USP coll., E-13162. Paratypes: same collection data as the holotype, specimens SP53-1 [FLePe], SP53-3 [FLePe], SP55(1) [F, one wing removed from adult and mounted on microscope slide], SP55(3) [F, one wing removed from adult and mounted on microscope slide], SP55a [F], SP55b [F]. The holotype and paratypes are deposited in the Coleção Entomológica da FSP-USP.

Other specimens examined - Brazil, SP, municipality of Campos do Jordão, Sallum \& Wilkerson coll. 20Nov-2001, Sallum det., 2001 [identified as An. near antunesi, FSP-USP E-12370, LePe]; Fazenda Saint Claire (-22,75847222S, -45,51527778W, Datum SAD69), Nagaki et al. coll., 27-Jan-2009, Nagaki \& Sallum det., 2009: SP51-100 [Pe mounted on microscope slide], SP53-4 [Le mounted on microscope slide], SP53-5 [Le mounted on microscope slide], SP53-100 [PeMG mounted on microscope slide], SP53-101 [FPe, one wing and three legs removed from adult and mounted on microscope slide].

Specimens of An. pristinus used to generate COI and ITS2 sequences were collected in Brazil, SP, municipality of Campos do Jordão, Sallum \& Wilkerson. coll., 20-Nov-2001, Sallum det., 2001: E-12370 [identified as An. near antunesi, only the abdomen]; Fazenda Saint Claire (-22,75847222S, -45,51527778W, Datum SAD69), Sallum et al. coll., 27-July-2006, Sallum det., 2006, in Shannon trap: VP11a [F], VP11d [F], Nagaki et al. coll., 27-Jan-2009, Nagaki \& Sallum det., 2009: SP51-100 [F], SP53-100 [M], SP53-101 [F], SP53-4 [P], SP53-5 [P]; in Shannon trap: SP50a [F], SP50b [F], SP55(2) [F], SP55(4) [F].

\section{DISCUSSION}

Morphological studies of anophelines from Pico do Itapeva showed that specimens could be separated into two morphotypes based on the pattern of pale and dark wing spots, male genitalia and fourth-instar larvae. Detailed comparisons of specimens from both localities showed that individuals from Itatiaia belong to $\mathrm{An}$. antunesi and that there was a second species in Pico Itapeva, which is herein formally named and described as $A n$. pristinus. The ITS2 and COI sequences corroborated the morphological hypothesis of two species.

In the larval stage, An. antunesi and An. pristinus can be easily recognized as members of the Myzorhynchella Section by having abdominal seta 6-IV-VI branched; in the adult stage by the absence of both scales and posterolateral scales tufts from all abdominal segments and hindtarsomeres 3-5 white-scaled; by the male genitalia in having the dorsal claspette with two setae arising from the apex and one subapical seta and the accessory setae ending in a sharply acute apex (Galvão 1941). An. antunesi, An. pristinus and An. lutzii can be distinguished from An. nigritarsis in the adult stage by the absence of dark scales on hindtarsomeres 3 and 4 (these hindtarsomeres are white-scaled with a dark basal band in $A n$. nigritarsis). Furthermore, An. antunesi, An. pristinus and An. lutzii can be separated from An. parvus by characters of the aedeagus of the male genitalia. In An. parvus the apex of the aedeagus is hook-like medially, with the lateral edges hyaline, whereas in An. lutzii, An. antunesi and An. pristinus the apex is flat, somewhat rounded, never hook-like. An. antunesi and An. pristinus can be separated from An. lutzii by having the aedeagal leaflets borne laterally, approximately parallel to the longitudinal axis of the aedeagus, whereas in An. lutzii the aedeagal leaflets arise laterally forming a $45^{\circ}$ angle with the longitudinal axis of the aedeagus. Additionally, characteristics of the dark and pale wing spots can distinguish An. antunesi and An. pristinus from An. lutzii and An. parvus. An. parvus has three dark spots on vein $\mathrm{R}_{4+5}$ separated by two well-defined white spots, whereas in $A n$. lutzii $\mathrm{R}_{4+5}$ is mostly dark-scaled with one preapical and one postbasal white spot. In An. antunesi and An. pristi$n u s$, vein $\mathrm{R}_{4+5}$ is mostly pale-scaled with one preapical and one postbasal dark spot. However, specimens of $A n$. antunesi from Itatiaia have vein $\mathrm{R}_{4+5}$ either mostly dark or mostly pale-scaled. Galvão (1941) considered that $A n$. antunesi and An. lutzii could be misidentified because of the polymorphisms of vein $\mathrm{R}_{4+5}$, with individuals of $A n$. antunesi having this vein mostly dark-scaled.

An. antunesi and An. pristinus can be distinguished by the pattern of dark and pale scales on vein $\mathrm{CuA}_{2}$. In An. antunesi, $\mathrm{CuA}_{2}$ is white-scaled on the proximal 0.5 and dark on the distal 0.5, whereas in An. pristinus $\mathrm{CuA}_{2}$ has a proximal pale spot, a dark spot, a pale spot and a distal dark spot (Fig. 2A, B). Consequently, the pattern 
of pale and dark spots on $\mathrm{CuA}_{2}$ can be used to identify An. antunesi and An. pristinus. In the male genitalia, An. pristinus can be separated from An. antunesi by having the apex of the ventral claspette moderately rounded apically (Fig.1B), the proctiger spiculate (Fig. 1C) and the ventromesal subtriangular projection positioned approximately at midlength of the insertion and the apex of the leaflets (Fig. 1F). In An. antunesi, the apex of ventral claspette is somewhat straight (Fig. 1A), the proctiger is bare (Fig. 1C) and the ventromesal subtriangular projection is positioned distally, approximately at the apex of the leaflets (Fig. 1E). Fourth-instar larvae of An. antunesi can be distinguished from those of An. pristinus by having seta 1-II-VII palmate with a short pedicel (Fig. 3A) and seta 6-IV-VI bifid (Fig. 3E), whereas in An. pristinus seta 1-II-VII has a long pedicel supporting thin hyaline leaflets (Fig. 3B) and seta 6-IV-VI is branched, with a central branch from which arise lateral branches (Fig. $3 F)$. Characters of the eggs as seen by SEM can also distinguish An. antunesi and An. pristinus. The deck tubercles of the An. antunesi egg are larger and closer together than they are on the An. pristinus egg (Fig. 4C, F). The outer chorion of the ventral surface is covered with circular pores in An. antunesi (Fig. 4B, D), whereas it has several irregular cracked areas in An. pristinus (Fig. 4E). Based on these observations it seems likely that Forattini et al. (1998) described the eggs of An. pristinus.

The hypothesis for a new, species sympatric with An. antunesi in Pico do Itapeva, Serra da Mantiqueira as observed by morphological differences in few specimens was corroborated by the ITS2 rDNA and COI sequences. ITS2 rDNA and COI sequences reveal that An. antunesis and An. pristinus are distinct species. The ITS2 sequences of different individuals of each species are identical; however, comparisons between the two species show indels among individuals. ITS2 differences between An. antunesis and An. pristinus are consistent, suggesting that these differences represent inter-specific variation. The COI sequence variation between An. antunesi and An. pristinus also corroborates the morphological and ITS2 sequence data, confirming An. pristinus as a new species.

\section{ACKNOWLEDGMENTS}

To Saint' Clair de Vasconcelos, for hosting fieldwork in Fazenda Saint Claire, Pico do Itapeva, Serra da Mantiqueira, to Ralph E Harbach, Natural History Museum, UK, and to the two anonymous reviewers for their great contribution to the improvement of the text.

\section{REFERENCES}

Belkin JN 1962. The mosquitoes of South Pacific (Diptera: Culicidae), University of California Press, Berkley and Los Angeles, 608 pp.

Belkin JN, Schick RX, Heinemann SJ 1971. Mosquito studies (Diptera: Culicidae). XXV. Mosquitoes originally described from Brazil. Cont Amer Entomol Inst 7: 1-64.

Cardoso JC, Corseuil E, Barata JMS 2004. Anophelinae (Diptera: Culicidae) ocorrentes no estado do Rio Grande do Sul, Brasil. Entomol Vect 11: 159-177.

Consolim J, Pellegrini NJM, Luz E 1993. Culicídeos (Diptera: Culicidae) do Lago Itaipu, Paraná, Brasil. I. Município de Foz do Iguaçu. Acta Biol Par 22: 83-90.
Darsie RF 1985. Mosquitoes of Argentina. Part I. Keys for identification of adult females and fourth stage larvae in English and Spanish (Diptera: Culicidae). Mosq Syst 17: 153-253.

Deane LM, Neto JAF 1969. Malária em macacos do Rio Grande do Sul. Obervações preliminares. Rev Inst Med Trop 11: 299-305.

Djadid ND, Gholizadeh S, Tafsiri E, Romi R, Gordeev M, Zakeri S 2007. Molecular identification of Palaearctic members of Anopheles maculipennis in Northern Iran. Malar J 6: 6.

Faran ME 1980. Mosquito studies (Diptera: Culicidae) XXXIV. A revision of the Albimanus Section of the subgenus Nyssorhynchus of Anopheles. Contrib Am Entomol Inst 15: 1-215.

Folmer O, Black M, Hoeh W, Lutz R, Vrijenhoek R 1994. DNA primers for amplification of mitochondrial cytochrome c oxidase subunit I from diverse metazoan invertebrates. Mol Mar Biol Biotechnol 3: 294-299.

Forattini OP 1962. Entomologia médica, vol. I, Faculdade de Higiene e Saúde Pública, São Paulo, 662 pp.

Forattini OP 2002. Culicidologia médica. Identificação, biologia, epidemiologia, vol. II, Edusp, São Paulo, 864 pp.

Forattini OP, Marucci D 1993. The scanning electron microscopy of Anopheles (Kerteszia) eggs. Mem Inst Oswaldo Cruz 88: 349-352.

Forattini OP, Sallum MAM, Bergo ES, Flores DC 1998. Ultrastructure of eggs of Anopheles rondoni, Anopheles lutzii, and Anopheles parvus, three species of the subgenus Nyssorhynchus. J Am Mosq Control Assoc 14: 256-265.

Forattini OP, Rabello EX, Cotrim MD 1970. Catálogo das coleções entomológicas da Faculdade de Saúde Pública da Universidade de São Paulo. $1^{a}$ série. Culicidae. Série Monográfica $\mathrm{n}^{\circ} 1 . R e v$ Saude Publica 4: 5-100.

Forattini OP, Sallum MAM, Marques GR, Flores DC 1997. Description of the eggs of Anopheles (Kerteszia) laneanus and Anopheles (Nyssorhynchus) antunesi (Diptera: Culicidae) by scanning electron microscopy. J Am Mosq Control Assoc 13: 368-374.

Galvão ALA 1940. Contribuição ao conhecimento dos anofelinos do grupo Nyssorhynchus de São Paulo e regiões vizinhas (Díptera: Culicidae). Arq Zool 1: 399-484.

Galvão ALA 1941. Contribuição ao conhecimento das espécies de Myzorhynchella (Diptera: Culicidae). Arch Zool S Paulo 2: $505-576$.

Galvão ALA, Amaral ADF 1940. Estudos sobre os anofelinos do grupo Myzorhynchella com a descrição de uma espécie nova, Anopheles (Nyssorhynchus) antunesi $\mathrm{n}$. sp. (Diptera: Culicidae). Folia Clin Biol 12: 150-160.

Gorham JR, Stojanovich CJ, Scott HG 1967. Clave ilustrada para los mosquitos anofelinos de Sudamerica Oriental, National Communicable Disease Center, Atlanta, 62 pp.

Harbach RE 2008. Mosquito taxonomic inventory. Available from: http://mosquito-taxonomic-inventory.info/. [accessed on the 2nd March 2010].

Harbach RE, Knight KL 1980. Taxonomists' glossary of mosquito anatomy, Plexus Publishing Inc, Marlton, $415 \mathrm{pp}$.

Knight KL, Stone A 1977. A catalog of the mosquitoes of the world (Diptera: Culicidae), vol. 6, Thomas Say Foundation, Washington DC, $611 \mathrm{pp}$.

Linthicum KJ 1988. A revision of the Argyritarsis Section of the subgenus Nyssorhynchus of Anopheles (Diptera: Culicidae). Mosq Syst 20: 98-271.

Maddison DR, Maddison WP 2000. MacClade 4: analysis of phylogeny and characters evolution, Version 4.0, Sinauer Associates Inc, Sunderland, Massachusetts. 
Motoki MT, Wilkerson RC, Sallum MA 2009. The Anopheles albitarsis complex with the recognition of Anopheles oryzalimnetes Wilkerson and Motoki, n. sp. and Anopheles janconnae Wilkerson and Sallum, n. sp. (Diptera: Culicidae). Mem Inst Oswaldo Cruz 104: 823-850.

Rachou RG, Ricciardi I 1951. Contribuição ao conhecimento da dIstribuição geográfica dos anofelinos no Brasil: estado do Paraná (distribuição por municípios e localidades). Rev Bras Malariol Doencas Trop 3: 423-447.

Rebêlo JMM, Moraes JLP, Alves, GA, Leonardo FS, Rocha RV, Mendes WA, Costa E, Câmara LEMB, Silva MJA, Pereira YNO, Mendonça JAC 2007. Distribution of species from genus Anopheles (Diptera: Culicidae) in the state of Maranhão, Brazil. Cad Saude Publica 23: 2959-2971.

Rodriguez MF, Varela JC 1962. Anopheles (Myzorhynchella) antunesi, especie nueva para el Uruguay. An Fac Montevideo 47: 246-249.
Rosa-Freitas MG 1989. Anopheles (Nyssorhynchus) deaneorum: a new species in the albitarsis complex (Diptera: Culicidae). Mem Inst Oswaldo Cruz 84: 535-543.

Sallum MAM, Wilkerson RC 1997. Description of immatures stages of Anopheles (Nyssorhynchus) rondoni (Neiva \& Pinto) (Diptera: Culicidae). Mem Inst Oswaldo Cruz 92: 365-372.

Swofford, DL 2003. PAUP*. Phylogenetic Analysis Using Parsimony (*and other methods), Version 4., Sinauer Associates Inc, Sunderland, Massachusetts.

Thompson JD, Gibson TJ, Plewniak F, Jeanmougin F, Higgins DG 1997. The Clustal X windows interface: flexible strategies for multiple sequence alignment aided by quality analysis tools. Nucleic Acids Res 24: 4876-4882.

Wilkerson RC, Peyton EL 1990. Standardized nomenclature for the costal wing spots of the genus Anopheles and other spotted-wing mosquitoes (Diptera: Culicidae). J Med Entomol 27: 217-224. 